Ann. Biol. anim. Bioch. Biophys., 1978, 18 (5), 1141-1153.

\title{
An ultrastructural study of early germ cells in Mugil (Liza) auratus Risso, 1810 (Teleostei : Mugilidae)
}

par Solange BRUSLÉ, J. BRUSLÉ

Laboratoire de Biologie Marine, Université de Perpignan 66025, France.

Summary. Using morphological and cytological criteria, 5 types of early germ cells, i. e. primordial germ cells, spermatogonia and primary spermatocytes and oogonia and primary oocytes, were recognized in mullet by electron microscopy. These have been compared with other fish and vertebrates and the gonial potentialities evaluated.

\section{Introduction.}

Grey mullet are heterosexual fish. A cytological analysis of germ cells was carried out using light microscopy in Mugil cephalus by Stenger (1959) and in M. auratus, $M$. labrosus and $M$. ramada by Leray (1968), Thong (1969) and Cassifour (1975). However, cellular characteristics were not sufficiently well defined at this level, and these data did not describe primordial germ cells or make any distinction between oogonia and spermatogonia.

Early germ cells were studied by electron microscopy chiefly on freshwater species such as Oryzias (Hogan, 1973 ; Satoh, 1974 ; Grier, 1976), Poecilia (Grier, 1975), Carassius (Kanobdee, 1975 ; Remacle ef al., 1977), Brachydanio (Baumeister, 1976), Salmo (Upadhyay, 1977). Investigations on marine species are rather scarce (Squalus : Holstein, 1969 ; Spicara : Carrillo and Zanuy, 1977 ; Scyliorhinus : Dobson and Dodd, $1977)$ and provide neither information concerning primordial germ cells nor comparison between oogonia and spermatogonia.

It thus seemed of interest to use electron microscopy to define the cytological characteristics of early germ cells in the juvenile and the yound golden-grey mullet Mugil (Liza) auratus.

\section{Material and methods.}

Juvenile and young golden-grey mullet Mugil (Liza) auratus of 10 to $30 \mathrm{~cm}$ in body length were caught by electric fishing in the brackish waters of the Leucate, a mediterranean lagoon at the Font Estramar Station (coastal springs $18^{\circ} \mathrm{C}$ ).

The gonads were fixed by immersion in 2 p. 100 glutaraldehyde fixative for $3 \mathrm{hrs}$ at $4{ }^{\circ} \mathrm{C}$, buffered to $\mathrm{pH} 7.3$ with $0.12 \mathrm{M}$ cacodylate buffer $; \mathrm{CaCl}_{2}$ was added as suggest- 
ed by Busson-Mabillot (1971). After washing in buffer overnight, the samples were postfixed in 2 p. 100 osmium tetroxide for $2 \mathrm{hrs}$, dehydrated in a graded ethanol series and finally embedded in epon. Uitrathin sections were stained with uranyl acetate solutions and lead citrate (Reynolds, 1963) and examined under a Hitachi-12A electron microscope.

\section{Results.}

\section{Stages of differentiating juvenile and young gonads}

The topographic features were first shown by light microscopy on semithin sections (Bruslé and Bruslé, 1977b, plate 1).

1) Undifferentiated gonads are observed in juvenile fish of 10 to $16.5 \mathrm{~cm}$ total body lengh ; they consist of connective tissue containing scattered germ cells and bordered by an epithelium. Germ cells are scarce, or even absent in specimens 10 to $12 \mathrm{~cm}$ long; these cells become more numerous as body length increases.

2) Ovarian differentiation may be divided into three stages :

- juvenile females (body length : 14 to $17 \mathrm{~cm}$ ) : connective tissue colonized chiefly by oogonia with scattered previtellogenetic oocytes ;

- young females (body length : 16.5 to $19 \mathrm{~cm}$ ) : gonadal organization characterized by developing parallel ovarian lamellae including many oogonia and some previtellogenetic oocytes;

- later (body length : $17.5 \mathrm{~cm}$ ) : oogonia less numerous, being replaced chiefly by previtellogenetic oocytes and some meiotic oocytes.

3) Testicular differentiation : fish must have 19 to $20 \mathrm{~cm}$ body length before the testes can be distinguished. Between 14 and $19 \mathrm{~cm}$ body length, gonads which are not female cannot be differentiated by light microscopy.

\section{PLATE'}

FIG. 1. - Primordial germ cell (PGC). $\times 12600$.

FIG. 2. - Whorl around mitochondria in a PGC. $\times 14500$.

FIG. 3. - Mitochondrial aggregate in a PGC. $\times 17600$.

Abbreviations. - Ce : centriolus ; $c$ : cement material ; $\mathrm{CB}$ : cyloplasmic bridge ; $\mathrm{Ch}$ : chromatin or chromosomes ; d : desmosome ; er : endoplasmic reticulum ; $G$ : golgi ; $m$ : mitochondria ; $\mathrm{mg}$ : mitochondrial aggregate $; \mathrm{n}:$ : nuage » material ; $\mathrm{N}$ : nucleus; $\mathrm{Ne}:$ nuclear envelope ; NSC : neighbouring somatic cell ; $\mathrm{Nu}$ : nucleolus ; OG : oogonium ; OOC : primary oocyte; PGC : primordial germ cell ; Pm : plasmic membrane; $r$ : ribosomes; SC : synaptonemal complex; SPC : primary spermatocyte; SPG : spermatogonium; wh : whorl.

(The bar is one micron for every micrograph.) 
Two stages were noted:

- juvenile males (body length : 20 to $23 \mathrm{~cm}$ ) : spermatogonia packed in nests located in the stroma; a few spermatocytes I in the beginning of meiotic process are observed ;

- young males (body length : 23 to $27 \mathrm{~cm}$ ) : gonadal organisation characterized by many cysts includes spermatogonia and more numerous spermatocyles I than in the previous stage.

\section{Fine structure of germ cells}

Five cell types, i. e. primordial germ cells (PGC), spermatogonia (SPG), primary spermatocytes (SPC), oogonia (OG) and primary oocytes (OOC) were recognized using topographical, morphological and cytological criteria (Bruslé and Bruslé, 1977b, plate II).

1) Primordial germ cells (PGC) (plate I).

a) Morphology : The cells are oval-shaped, being $13.5 \pm 1.8 \mu \mathrm{m}$ in length and $9.5 \pm 1.7 \mu \mathrm{m}$ in width ; they are characterized by heavy electron cytoplasm density and have a very irregular outline.

b) Cytology - Nuclear characteristics : The nucleus is voluminous (Nucleus/Cytoplasm $=038 \pm 007$ ) and eccentrically located The outline of the nuclear envelope is irregular and the nucleoplasm contains a finely granular and widely dispersed chromatin. The single nucleolus situated eccentrically consists of a small fibrillar center and a large, coarse, segregated granular cortex (fig 1).

- Cytoplasmic characteristics : Many ribosomes are freely dispersed throughout the cytoplasm making it very electron-dense. The rather extensive granular-type endoplasmic reticulum is chiefly developed in the peripheral area; its membranes are concentrically organized (fig. 1) and occasionally form a whorl around the mitochondria (fig. 2). Golgi complexes are usually situated close to the nuclear envelope. Most of the mitochondria are round-shaped, 0.5 to $1 \mu \mathrm{m}$ in diameter, and randomly distributed throughout the cytoplasm. Masses of electron opaque substance are observed outside the nuclear membrane either in contact with or at a short distance from it.

\section{PLATE ॥}

FIG. 4. - Spermatogonium. $\times 7700$.

FIG. 5. - Mitochondrial aggregate in a spermatogonium. $\times 15500$.

FIG. 6. - Primary spermatocyte at the beginning of meiotic prophase. $\times 16800$.

FIG. 7. - Nucleus of a primary spermatocyte with synaptonemal complex at pachytene stage. $\times 18000$.

FIG. 8. - Intercellular bridge between two primary spermatocytes. $\times 13750$. 
These aggregates, generally characterizing germ cells, are of two types according to their distribution (figs. 1, 3) : independent and so called « nuage » aggregates, or those joining mitochondria and called «ciment» (cement) (Clérot, 1968, 1976). The latter mitochondria which occur in clusters around and close to the cement material and are highly compacted with it, constitute " groupements mitochondriaux 》 (mitochondrial aggregates) according to André $(1962)$ and Clérot $(1968,1976)$. No further inclusions (lipid, glycogen) were found in the cytoplasm and no special relationships between the PGC and the neighbouring somatic cells were observed.

2) Spermatogonia (plate II, figs. 4,5 ).

a) Morphology : The cells are oval-shaped and of slightly irregular outline, having a mean length of $14.2 \pm 3.3 \mu \mathrm{m}$ and a mean width of $10.5 \pm 2.5 \mu \mathrm{m}$.

b) Cytology - Nuclear characteristics (fig. 4) : The nucleus is still extensive (Nucleus/Cytoplasm $=0.40 \pm 0.06$ ), oval-shaped and eccentric with a slightly irregular envelope. The chromatin appears rather granular and dispersed, but small dense clumps are found associated with the nucleolus and are also more densely packed on the perimeter close to the nuclear membrane. The nucleolus, approximately $2 \mu \mathrm{m}$ in diameter and eccentrically located, consists of a larger fibrillar center and a denser, thinner granular cortex than observed in PGC.

- Cytoplasmic characteristics (figs. 4, 5) : Free ribosomes are less numerous than in PGC and the electron density of spermatogonia is consequently lower than that of neighbouring somatic cells. The granular endoplasmic reticulum is roughly concentric with the nucleus and the plasma membrane and shows occasional whorls. A few juxtanuclear dictyosomes are gathered close to the nucleus. The mitochondria are generally round-shaped and 0.5 to $1 \mu \mathrm{m}$ in diameter (average : $0.66 \mu \mathrm{m}$ ) with a rather dense matrix. Because of the eccentric nuclear position, mitochondria show a crescentshaped distribution with no true polarify. The electron-dense material is not different from that of PGC (isolated «nuage » and cement material interspersed with mitochondrial aggregates) (fig. 5). Neither intercellular bridges nor desmosomes are present.

3) Primary spermatocytes (plate II, figs. 6, 7, 8).

a) Morphology : The cells are oval-shaped with an almost regular outline; they are smaller in size than spermatogonia (11.5 $\pm 2 \mu \mathrm{m}$ in length and $7 \pm 1.6 \mu \mathrm{m}$ in width) and present no evidence of growth (auxocytosis, Clérot, 1976).

b) Cytology - Nuclear characteristics (fig. 6) : The nucleus is eccentrically located, oval-shaped or even nearly round, with a rather regular outline. As meiosis proceeds. the nucleus, already voluminous at the onset of prophase, increases (Nucleus/Cytoplasm $=0.54 \pm 0.08$ ), and the surrounding cytoplasm is reduced to a narrow strand sparsely populated in organelles. The single nucleolus, $1.5 \mu \mathrm{m}$ in diameter, situated eccentrically close to the regular nuclear envelope during leptotene-zygotene stages, disappears when synaptonemal complexes (fig. 7) become evident (pachytene-diplotene stages). 
- Cyfoplasmic characteristics : Free ribosomes are distributed as in the previous stage. The rough endoplasmic reticulum is much less abundant than in younger cells. A few dictyosomes are observed preferentially located in the vicinity of cytoplasmic bridges (fig. 8). The round or elongated mitochondria are generally smaller in diameter $(0.3$ to $0.5 \mu \mathrm{m})$, although some are the same $(0.66 \mu \mathrm{m})$ as those of the spermatogonial stages; there are generally few, exhibiting a rather dense matrix associated with dense material (cement) while « nuage » material is more scarce (fig. 6). These mitochondrial aggregates are packed with dictyosomes close to the intercellular bridges and give the primary spermatocyte a conspicuous polarity.

In conclusion, it is of interest to note the following distinctive changes from spermatogonia to spermatocytes : decreasing size, increasing nuclear-cytoplasmic ratio, disappearance of the nucleolus when synaptonemal complexes organize, reduction in the number of mitochondria, dictyosomes, mitochondrial aggregates and chiefly in the amount of endoplasmic reticulum; these organelles are polarized close to cellular bridges connecting two adjacent cells.

4) Oogonia (plate III, figs. 9, 10).

a) Morphology : The cells are oval or round-shaped and of almost regular outline, having a mean length of $14.3 \pm 2.2 \mu \mathrm{m}$ and a mean width of $11.34 \pm 3.3 \mu \mathrm{m}$.

b) Cytology - Nuclear characteristics (fig. 9) : The large ovoid or roughly spherical nucleus (Nucleus/cytoplasm $=0.41 \pm 0.08$ ) is situated almost centrally and has a regular outline. The chromatin is circumnuclearly distributed. The prominent, single nucleolus, larger than in spermatogonia ( $>2 \mu \mathrm{m}$ in diameter), is roughly spherical with a concentric distribution of the fibrillar center and the granular cortex.

- Cytoplasmic characteristics : The cytoplasm exhibits free ribosomes which are fewer in number than in PGC and consequently have lower electron density. The endoplasmic reticulum, irregularly positioned, is not extensive; it is dispersed and occasionally organized in whorls (fig. 9). Some Golgi complexes are confined to the perinuclear area. Mitochondria are generally round and 0.6 to $1 \mu \mathrm{m}$ in diameter. The " nuage » material (figs. 9,10 ) is of two types, dense and less dense, and occurs adjacent to the nuclear envelope, close to the nuclear pores; the cement material (fig. 10) is surrounded by mitochondrial aggregates as in spermatogonia. There is no evidence of inclusion, intercellular bridges or desmosomes; folliculogenesis was not initiated.

Oogonia are thus distinguished from spermatogonia by the following main features : more regular cell outline, less extensive endoplasmic reticulum, spherical nucleus with regular envelope almost centrally located and a larger nucleolus.

5) Early oocytes (meiotic prophase) (plate III, figs. 11, 12).

a) Morphology : The cells are ovoid, having a mean length of $11.8 \pm 2 \mu \mathrm{m}$ and a mean width of $7.5 \pm 1.3 \mu \mathrm{m}$.

b) Cytology - Nuclear characteristics : The oval-shaped and slightly eccentrically located nucleus is well developed (Nucleus/Cytoplasm $=0.55 \pm 0.07$ ) and occupies the greater part of the cell. The single nucleolus begins to disappear concomitantly with synaptonemal organization at the pachytene stage (fig. 11). 
- Cytoplasmic characteristics: The cytoplasm is reduced to a thin peripheral layer, the nuclear envelope often being tangent and close to the plasma membrane; it is poor in organelles (fig. 11). Free ribosomes appear as dense as in the oogonial stage. Endoplasmic reticulum is scarce, dispersed and irregularly positioned. Golgi complexes are few in number and located close to intercellular bridges (fig. 12) which connect adjacent primary oocytes. Mitochondria are generally round and small $(0.2$ to $0.66 \mu \mathrm{m}$ in diameter) and their configuration is the same as primary spermatocytes. These few mitochondria are chiefly aggregated adjacent to the cement material, while that of the "nuage " becomes more scarce. The most consistent feature is the polarity due to the mitochondrial aggregates distributed between the nuclear envelope and the cytoplasmic bridges (fig. 12). The striking changes observed in the morphology of oocytes as compared to that of oogonia are similar to those shown in male differentiation.

\section{Discussion and conclusion.}

Chronology of sex differentiation. - The gonadal tissue being undifferentiated in the smallest fish, sex cannot be recognized in juvenile grey mullet. Males and females are distinguished at a rather late period in Mugil auratus, i. e. during the second year of life (Thong, 1969, Birttany, over $18 \mathrm{~cm}$ fork length ; Chervinski, 1976, Israel).

Our data reveal that the colonization of somatic tissues by PGC is late. No germ cell is evident in the gonad until a total body length of 9 to $10 \mathrm{~cm}$ is reached when the fish are about 8 months old.

As shown in other fish, the onset of sex differentiation in females is earlier than in males; the ovary organizes from 13 to $14 \mathrm{~cm}$ body length, while the testis organizes from 19 to $20 \mathrm{~cm}$ total body length. This onset of sex differentiation occurs at the end of the first year for the females and at the beginning of the second year for the males, and therefore earlier than observed by Ezzat (1965), Cassifour (1975) and Chervinski (1976) in Mugil auratus.

Using electron microscopy, we were able to identify the sex of « undifferentiated » gonads from some males and females having 13 to $16 \mathrm{~cm}$ body length and from some males measuring 16 to $19 \mathrm{~cm}$ body length.

The chronology of sex differentiation is probably labile and related to growth and sexual maturation which vary greatly, depending on ecological factors and food supply.

PLATE III

FIG. 9. - Oogonium $\times 7750$.

FIG. 10. - «Nuage », cement material and mitochondria in oogonium. $\times 13200$.

FIG. 11. - Primary oocyfe with synaptonemal complexes af pachyfene stage. $\times 16500$.

FIG. 12. - Intercellular bridge connecting two adjacent primary oocytes. $\times 12000$. 


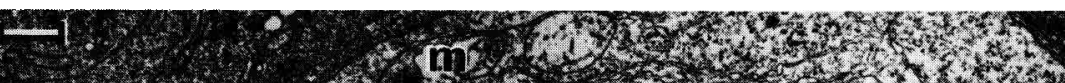

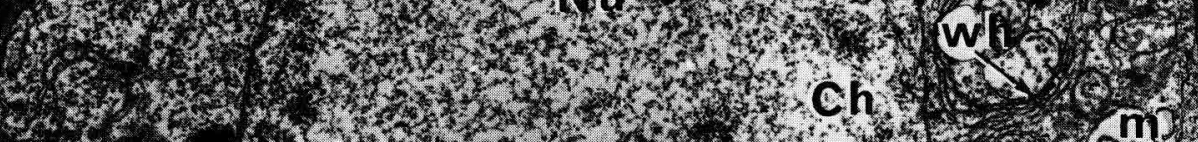

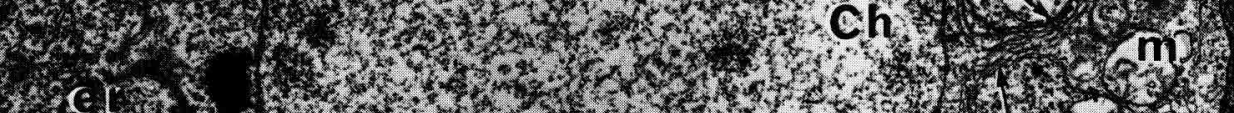

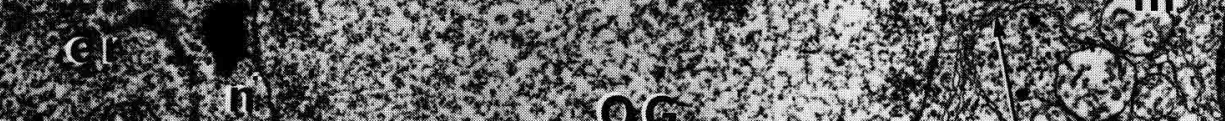

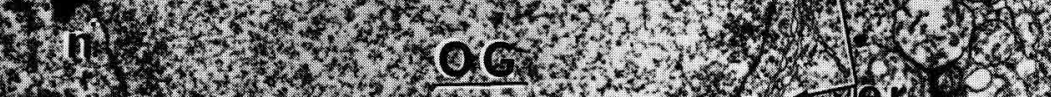

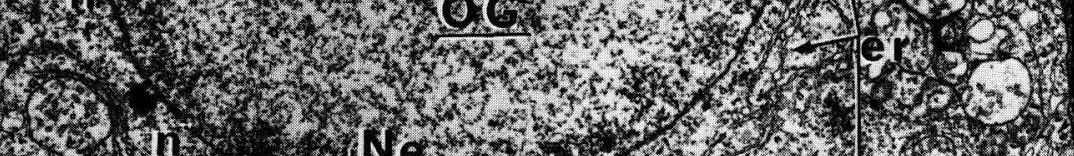

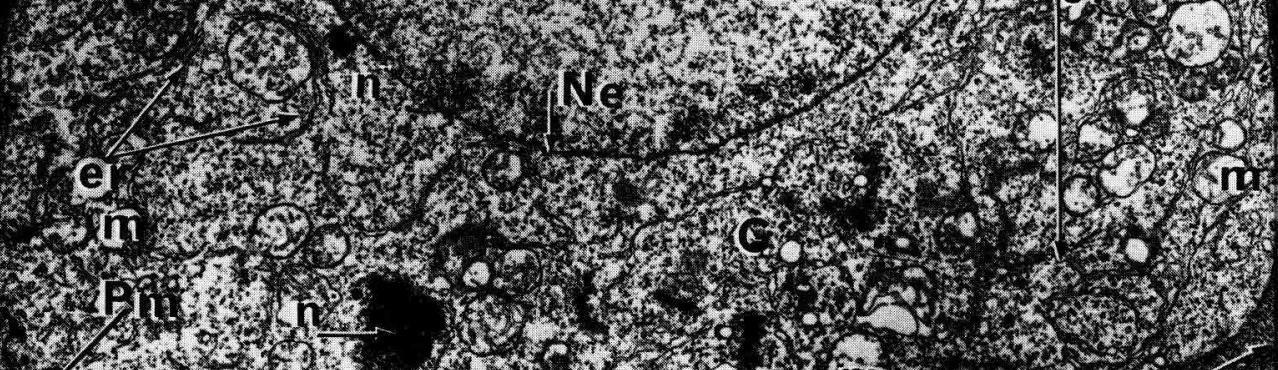

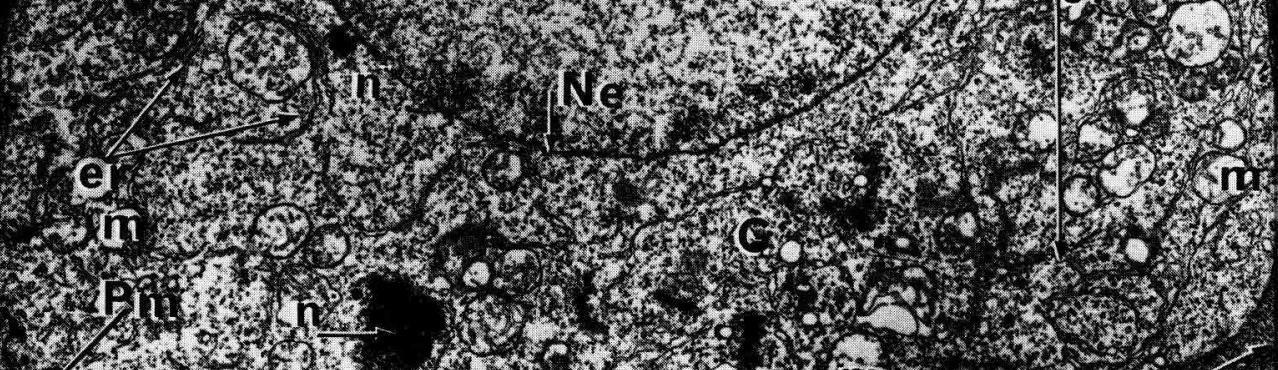

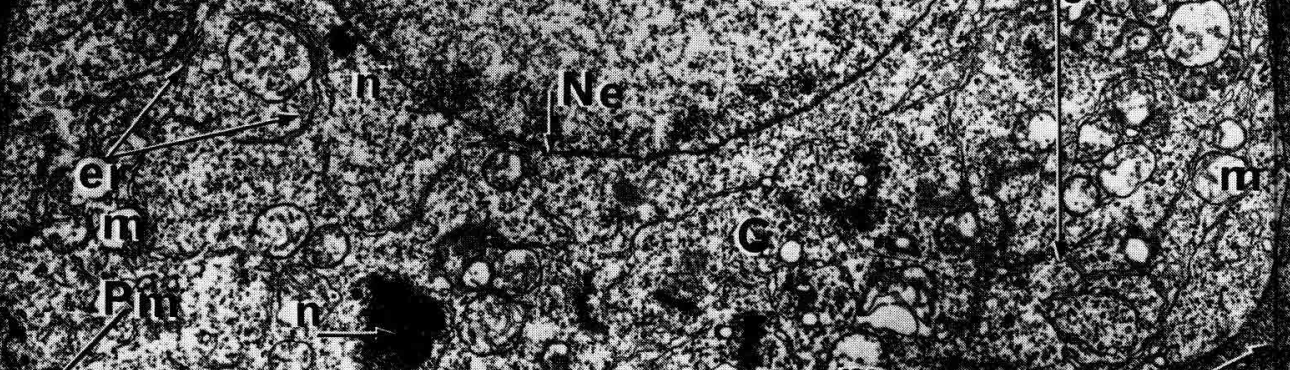

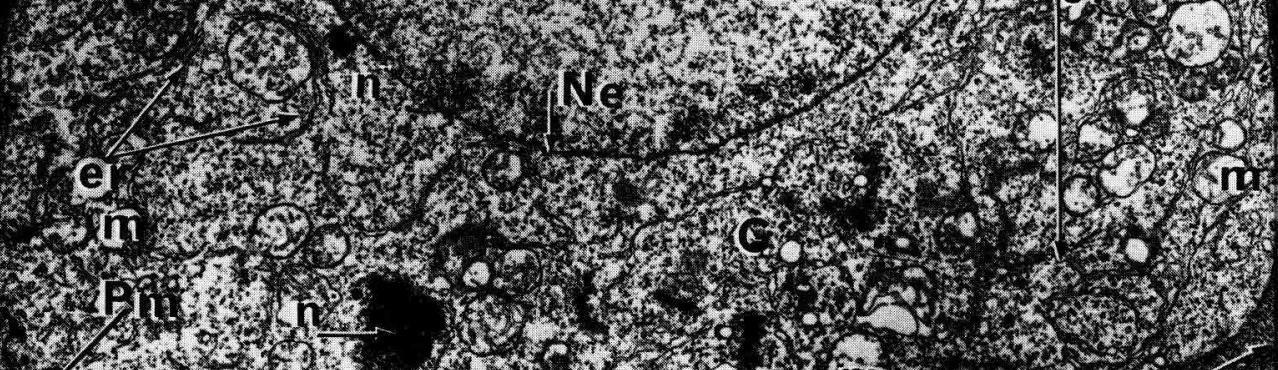

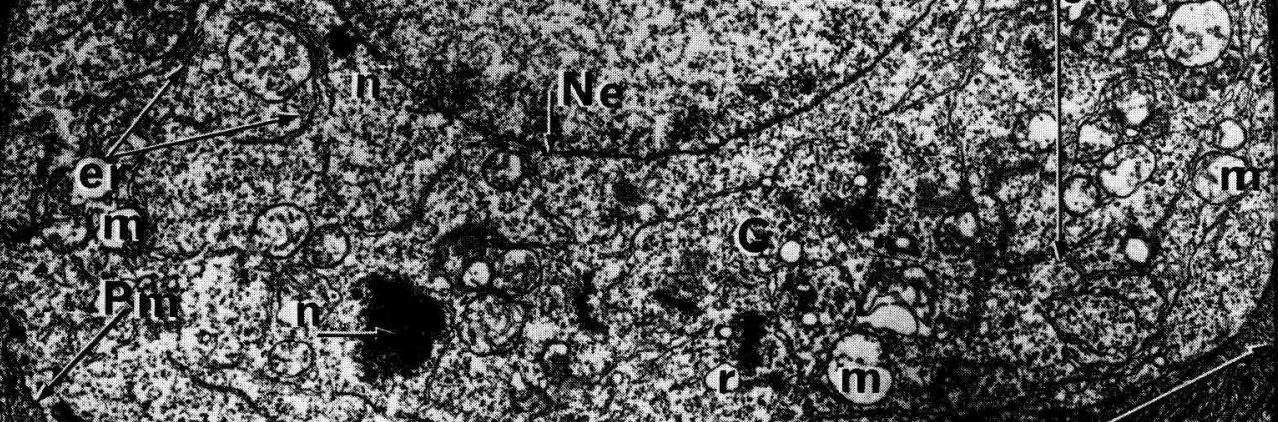
2.

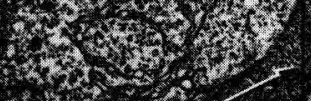

Fin

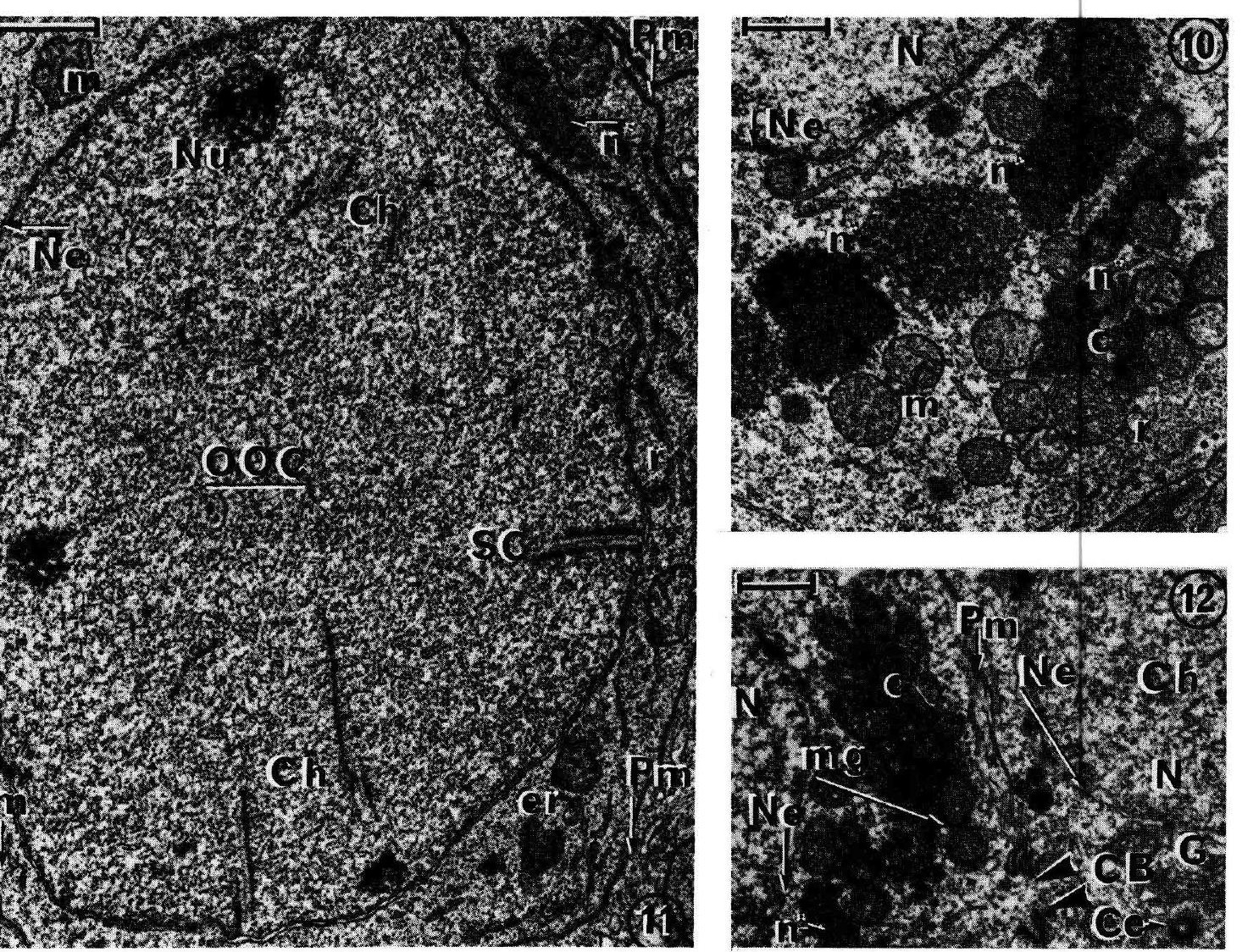


Thus, golden-grey mullet are known to first enter sexual maturation during their third or fourth year or even later (Nikolskii, 1961 ; Ezzat, 1965 ; Abraham et al., 1966 ; Thong, 1969).

Fine structure of germ cells. - Early germ cells are quite evident in electron microscopy and are distinguishable from somatic cells by the presence of characteristic and prominent «dense bodies» in the cytoplasm. Much attention was focused on this dense material, more or less closely associated with mitochondrial aggregates, because it is considered as a « marker of germ cells 》 (Hogan, 1973). In different species of fish it has been termed : « germinal dense bodies « (Satoh and Egami, 1973 and Satoh, 1974 in Oryzias), « granular bodies » (Azevedo, 1976, in Xiphophorus), « chromatoid bodies » (Schjeide et al., 1972, in Pimephales), « nuclear-like material » (Kanobdee, 1975, in Carassius), « granular masses » (Hogan, 1973, in Oryzias). We adopt the terminology used by André $(1962)$ and by Clérot $(1968,1976):$ «uage » for isolated, perinuclear or juxtanuclear material and «ciment » (cement) or «ciment intermitochondrial » (intermitochondrial cement material) when the mitochondria occur in a cluster packed close around the dense substance to constitute a « groupement mitochondrial » (mitochondrial aggregate). In our data, the « nuage » and cement material and the mitochondrial aggregates occur in PGC and gonia and decrease in further development.

The most conspicuous characteristics of PGC in golden-grey mullet are :

- very irregular cell outline, probably indicating ameboid movements during migration, as previously suggested in fish by Hogan (1973) and as known in other vertebrates (Hubert, 1974, 1976 ; Cuminge and Dubois, 1974 ; Fujimoto et al., 1975, 1976 ; Spiegelman and Bennett, 1973 ; Zamboni and Merchant, 1973 ; Clark and Eddy, 1975) ;

- many free ribosomes inducing heavy electron density; this does not confirm previous findings in fish (Hogan, 1973 ; Satoh, 1974) but agrees with observations on other vertebrates (Reed and Stanley, 1972 ; Ruby and Webster, 1972 ; Eddy, 1974) ;

- endoplasmic reticulum present, although the classical view is that embryonic cells are generally devoid of typical endoplasmic reticulum (it is shown to be absent in PGC of Oryzias, Satoh, 1974) ;

- nucleolar structure with a small fibrillar center; no comparative information is available in fish, but nucleolar evolution can be observed in reptilia (Hubert, 1974).

It appears probable that significant changes occur in the PGC during the early life history of the germ cell line, as shown in mammals (Clark and Eddy, 1975). Besides, transitional stages from PGC to gonia might be identified as these cells continue to become more specialized with time.

It is of interest to point out that cytological differences between gonia and PGC chiefly involve : more regular outline of the plasma membrane of gonia (mainly oogonia), reduction in the number free ribosomes and consequently a decrease in electron density, and finally change of nucleolus structure with a larger fibrillar center.

Spermatogonia and oogonia of golden-grey mullet are rather richly endowed with organelles; this contrasts with other studies on other fish in which the scarcity of organelles is clear during spermatogonial and oogonial stages (Satoh and Egami, 1973, in Oryzias ; Remacle et al., 1977, in Carassius ; Russo and Pisano, 1973, in Platypoecilus). The endoplasmic reticulum appears rather extensive in spermatogonia and less in 
oogonia, while it is shown to be absent in other fish (Acipenser : Raikova, 1970 ; Syngnathus and Hippocampus : Anderson, 1967 ; Fundulus : Anderson, 1968).

Our observations reveal some characteristics of male and female gonia and allow us to distinguish them. The spermatogonia exhibit a nucleus more eccentrically located than that of oogonia with denser chromatin frequently associated with the nucleolus and closely packed around the nuclear envelope. This euchromatic nucleus appears clearer and has a more regular outline in oogonia than in spermatogonia. However, earlier reports had suggested that no morphological or cytological differences were evident between oogonia and spermatogonia (Remacle et al., 1977). Other findings reveal that intercellular bridges occur between adjacent spermatogonia (Poecilia : Billard and Fléchon, 1969 ; Grier, 1975 ; Gardonus : Clérot, 1971 ; Platypoecilus : Russo and Pisano, 1973 ; Oryzias : Grier, 1976). Our observations fail to reveal similar bridges in golden-grey mullet.

At the onset of meiosis, striking changes occur in the morphology of germ cells as gametogenesis proceeds. As compared to spermatogonia and oogonia, the primary spermatocytes and oocytes are characterized by a decrease in the number of organelles and by a reduction in size which remains stable in further male development, while the oocytes start to grow intensely during auxocytosis and vitellogenesis. In meiotic spermatocytes and oocytes, the cement material is still present, but the "nuage » material becomes scarce. A similar situation was found in Oryzias by Hogan (1973), but this dense material disappears in the course of oocyte (Satoh, 1974) and spermatocyte (Grier, 1975) differentiation.

Gonial potentialities. - Our findings provide an indication of gonial potentialities. Similarity in the ultrastructural features of male and female PGC suggests that these undifferentiated cells are bipotential.

PGC are present in undifferentiated gonads and in small numbers in young, and even submature, ovaries and testes. They constitute a permanent stock in both sexes. Gonia may arise from these latent PGC at any time, usually according to genetic sex, but exceptionally when testicular intersexuality is found in different species of grey mullet (Orlandi, 1902 ; Stenger, 1959 ; Moe, 1966 ; Thong, 1969 ; Gandolfi et al., 1969 ; Bruslé and Bruslé, 1975, 1977a). PGC are probably responsible for this sexual lability.

Ruby and McMillan (1975) have discussed the problem of the origin of germ cells and the various conflicting opinions of different workers, but it is not studied here.

Reçu en décembre 1977.

Accepté en mars 1978.

Résumé. Une étude des gonades juvéniles du muge doré, effectuée en microscopie électronique, a permis d'identifier à l'aide de critères morphologiques et cytologiques cinq catégories de cellules germinales précoces : cellules germinales primordiales ou CGP, spermatogonies et spermatocytes I, ovogonies et ovocytes I. Ces résultats ont été comparés à ceux obtenus chez d'autres Poissons et chez les Vertébrés. Les potentialités goniales ont été estimées. 


\section{References}

ABRAHAM M., BLANC N., YASHOUV A., 1966. Oogenesis in five species of grey mullets (Teleostei, Mugilidae) from natural and landlocked habitats. Israel. J. Zool., 15, 155-72.

ANDERSON E., 1967. The formation of the primary envelope during oocyte differentiation in Teleosts. J. Cell Biol., 35, 193-212.

ANDERSON E., 1968. Cortical alveoli formation and vitellogenesis during oocyte differentiation in the pipefish, Syngnathus fuscus, and the killefish, Fundulus heferoclifus. J. Morph., 125, 23-60.

ANDRÉ J., 1962. La formation de mitochondries nouvelles dans les spermatocytes de rat. Vth. int. Congr. Electr. Micr., Philadelphie, 2, 00-1.

AZEVEDO C., 1976. Intranuclear membranous inclusions in oocytes of a viviparous Teleost (Xiphophorus helleri). J. Cell Sci., 22, 325-331.

BAUMEISTER H. G., 1976. Multiple Nukleolen und RNS-Synthese in der Oogenese von Brachydanio rerio (Teleostei). Zool. Jb. Anat. Bd., 95, 165-185.

BILLARD R., FLÉCHON J. E., 1969. Spermatogonies et spermatocytes flagellés chez Poecilia reticulata (Téléostéens cyprinodontiformes). Ann. Biol. anim. Bioch. Biophys., 9, 281-286.

BRUSLÉ S., BRUSLÉ J., 1975. Intersexualité testiculaire chez les muges méditerranéens Mugil cephalus et Mugil ramada. Bull. Soc. zool. fr., 100, 2-249.

BRUSLÉ S., BRUSLÉ J., 1977a. Sur la présence d'ovocyłes dans le testicule de Mugil auratus, poisson téléostéen gonochorique. Etude ultrastructurale et comparaison avec les ovocytes intraovariens. Biol. Cell, 29, 34a.

BRUSLÉ S., BRUSLÉ J., 1977b. An ultrastructural study of early sex-differentiation in Mugil (Liza) auratus RISSO, 1810 (Teleost, Mugilidae). Symposium on reproductive Physiology of fish, Paimpont, $19-21$ sept. 1977.

BUSSON-MABILLOT S., 1971. Influence de la fixation chimique sur les ultrastructures. I. Etude sur les organites du follicule ovarien d'un poisson Téléostéen. J. Micr., 12, 317-347.

CARRILLO M., ZANUY S., 1977. Quelques observations sur le festicule chez Spicara chryselis C. V. Inv. Pesq., 41, 121-146.

CASSIFOUR P., 1975. Contribution à l'étude de la biologie des Mugilidés des réservoirs à poissons du bassin d'Arcachon. Thèse $3^{\mathrm{e}}$ cycle Univ. Bordeaux, $104 \mathrm{pp}$.

CHERVINSKI J., 1976. Growth of the golden-grey-mullef (Lizo aurata) in saltwater ponds during 1974. Aquaculture, 7, 51-57.

CLARK J. M., EDDY E. M., 1975. Fine structural observations on the origin and associations of primordial germ cells of the mouse. Developm. Biol., 47, 136-155.

CLÉROT J.-C., 1968. Mise en évidence par cytochimie ultrastructurale de l'émission de protéines par le noyau d'auxocytes de Batraciens. J. Micr., 7, 973-992.

CLÉROT J.-C., 1971. Les ponts intercellulaires du festicule du gardon : organisation syncitiale et synchronie de la différenciation des cellules germinales. J. Ultrastruct. Res., 37, 690-703.

CLÉROT J.-C., 1976. Les groupements mitochondriaux des cellules germinales des poissons Téléostéens Cyprinidés. 1. Ełude ultrastructurale. J. Ultrastr. Res., 54, 461-475.

CUMINGE D., DUBOIS R., 1974. Embryologie expérimentale. Rôle des glycoprotéines dans la migration chimiotactique des cellules germinales du poulet, d'après les résulfats obtenus avec la concanavaline $A$ en culture organotypique. C. R. Acad. Sci. Paris, série D, 279, 995-998.

DOBSON S., DODD J. M., 1977. Endocrine control of the testis in the dogfish Scyliorhinus canicula L. II. Histological and ultrastructural changes in the testis after partial hypophysectomy (ventral lobotomy). Gen. comp. Endocr., 32, 53-71.

EDDY E. M., 1974. Fine structural observation on the form and distribution of nuage in germ cells of the rat. Anot. Rec., 178, 731-758.

EZZAT E., 1965. Contribution à l'étude de la biologie de quelques Mugilidae de la région de l'étang de Berre ef du Port de Bouc. Thèse Doct. sci. Aix Marseille, 225 pp.

FUJIMOTO T., UKESHIMA A., KIYOFUJI R., 1975. Light -and electron-microscopic studies on the origin and migration of the primordial germ cells in the chick. Acta anat. nippon., 50, 22-40.

FUJIMOTO T., UKESHIMA A., KIYOFUJI R., 1976. The origin, migration and morphology of the primordial germ cells in the chick embryo. Anat. Rec., 185, 139-154. 
GANDOLFI G., CARONNA E., ORSINI P., 1969. Ermafroditismo in Mugil soliens Risso (Pisces, Mugilidae). Boll. Pesca Piscic. Idrobiol., 24, 62-70.

GRIER H. J., 1975. Aspects of germinal cyst and sperm development in Poecilio latipinna (Teleostei : Poeciliidae). J. Morph., 146, 229-250.

GRIER H. J., 1976. Sperm development in the Teleost Oryzias latipes. Cell Tiss. Res., 168, 419-431.

HOGAN J. C., 1973. The fate and fine structure of primordial germ cells in the teleost, Oryzias latipes. J. Cell Biol., 59, $146 a$.

HOLSTEIN A. F., 1969. Zur Frage der lokalen Steuerung der Spermatogenese beim Dornhai (Squalus acanthias L.). Z. Zellf., 93, 265-281.

HUBERT J., 1974. Ultrastructure des gonocyles primordiaux du lézard des murailles (Lacerta muralis Laur.) et du lézard vert (Lacerta viridis Laur.). Comparaison avec le lézard vivipare (Lacerta vivipara J.). Arch. Anat. Hist. Embr. norm. et exp., 57, 259-268.

HUBERT J., 1976. Ultrastructure des ébauches gondiques du lézard vivipare (Lacerta vivipara Jacquin) pendant la période de colonisation par les gonocytes. Arch. Anat. Micr., 65, 241-254.

KANOBDEE D., 1975. Oogenesis in the goldfish (Carassius auratus L.) with particular reference to mitochondriogenesis. Ph. D. Thesis, Univ. Southampton U. K., 255 pp.

LERAY C., 1968. Etude histologique de l'hypophyse chez le muge ef la carpe : ses corrélations avec l'hypothalamus, la thyroide et les gonades. Thèse Doct. Sci. nat., Aix-Marseille, $n^{\circ} 2448,376$ pp.

MOE M. A., 1966. Hermaphroditism in Mullet, Mugil cephalus L. Q. J. Florida Acad. Sci., 29, 111-116.

NIKOLSKII G. V., 1961. Special ichthyology (Transl. from russian by Israel program for scientif. Transl., Jerusalem) $538 \mathrm{pp}$.

ORLANDI S., 1902. Sopra un caso di ermafroditismo nel Mugil chelo. Atti. Soc. Lig. Sci. nat. geogr. Genova, 112, 3-6.

RAIKOVA E. V., 1970. The ultrastructure of oogonia of the Volga sturgeon, Acipenser güldenstädti. Tsitologiya, 12, 827-833.

REED S. C., STANLEY H. P., 1972. Fine structure of spermatogenesis in the south african clawed toad Xenopus laevis D. J. Ultrast. Res., 41, 277-295.

REMACLE C., DELAERE P., HARRISSON F., JACQUET P., 1977. Contributions à l'étude de la différenciation des cellules germinales des poissons Téléostéens. Inv. Pesq., 41, 39-65.

REYNOLDS E. S., 1963. The use of lead citrate at high $\mathrm{pH}$ as an electron opaque stain in electron microscopy. J. biophys. biochem. Cytol., 17, 208-212.

RUBY S. M., MCMILLAN D. B., 1975. The interstial origin of germinal cells in the testis of the stickleback. J. Morph., 145, 295-318.

RUBY J. R., WEBSTER R. M., 1972. Origin of the Golgi complex in germ cells in the developing ovary of the Bat. Z, Zellf., 133, 1-12.

RUSSO J., PISANO A., 1973. Some ultrastructural characteristics of Platypoecilus maculatus spermatogenesis. Boll. Zool., 40, 201-207.

SATOH N., 1974. An ultrastructural study of sex differentiation in the Teleost. Oryzias latipes. J. Emb. exp. Morph., 32, 195-215.

SATOH N., EGAMI N., 1973. Preliminary report on sex differentiation in germ cells of normal and transplanted gonads in the fish, Oryzias latipes, 29-32. In SCHRODER J. H., Genetics and mutagenesis of fish. Springer-Verlag, Berlin.

SCHJEIDE O. A., NOCHOLLS T., GRAHAM G., 1972. Annulate lamellae and chromatoid bodies in the testes of a Cyprinid fish (Pimephales notatus). Z. Zellf., 129, 1-10.

SPIEGELMAN M., BENNETT D., 1973. A light-and electron-microscopic study of primordial germ cells in the early mouse embryo. J. Embryol. exp. Morph., 30, 97-118.

STENGER A. H., 1959. A study of the structure and development of certain reproductive tissues of Mugil cephalus L. Zool., 44, 53-70.

THONG L. H., 1969. Contribution à l'étude de la biologie des Mugilidés (poissons Téléostéens) des côtes du Massif armoricain. Trav. Fac. Sci. Univ. Rennes, Océanogr. biol., 2, 55-182.

UPADHYAY S. N., 1977. Morphologie des gonades immatures ef étude expérimentale de l'induction de la gametogenèse chez la truite arc-en-ciel juvénile (Salmo gairdneri R.). Thèse Doct. Sci. Univ. Paris $\mathrm{VI}, 111 \mathrm{pP}$.

ZAMBONI L., MERCHANT H., 1973. The fine morphology of mouse primordial germ cells in extragonadal locations. Am. J. Anat., 137, 299-336. 